\title{
Decision Support System Peramalan Permintaan Layanan Kecantikan dengan Single Exponential Smoothing dan Simple Moving Average
}

\author{
Harifzi Abdul Madjid ${ }^{\mathrm{a} 1}$, Awalludiyah Ambarwati ${ }^{\mathrm{a} 2}$, Latipah $^{\mathrm{b3}}$ \\ ${ }^{a}$ Sistem Informasi, Fakultas Ilmu Komputer, Universitas Narotama \\ ${ }^{1}$ harifzi.abdul@mhs. fasilkom.narotama.ac.id \\ 2awalludiyah. ambarwati@narotama.ac.id \\ ${ }^{b}$ Teknik Informatika, Fakultas Ilmu Komputer, Universitas Narotama \\ ${ }^{3}$ latifah.rifani@narotama.ac.id
}

\begin{abstract}
Abstrak
Permasalahan dalam menentukan keputusan strategi pemasaran dan manajemen persediaan sering terjadi pada setiap perusahaan. Pada penyedia layanan kecantikan permasalahan ini mengakibatkan penimbunan persediaan bahan treatment. Hal ini disebabkan oleh tidak rasionalnya keputusan decision maker dalam manajemen persediaan, terlalu ambisi dalam memenuhi permintaan sebanyak-banyaknya, sedangkan gairah pelanggan sedang mengalami lesu kemudian bertolak belakang dengan tawaran penyedia layanan kecantikan. Efek penimbunan bahan treatment dapat mengancam kualitas bahan treatment kemudian berimbas pada kerugian perusahaan. Adapun hal yang dapat mencegah penimbunan terjadi adalah pengetahuan peramalan permintaan. Pengetahuan peramalan permintaan dapat memberikan informasi tentang estimasi permintaan pelanggan pada masa depan. Kemudian decision maker dapat membuat keputusan terbaik dalam manajemen persediaan secara efisien, sehingga aplikasi pendukung keputusan sangat dibutuhkan. Data permintaan merupakan time-series dengan pola horizontal, sehingga metode peramalan yang digunakan adalah Simple Moving Average dan Single Exponential Smoothing. Aplikasi pendukung keputusan ini berbasis web aplikasi dengan bahasa pemrograman PHP orientasi objek dan framework tambahan Laravel. Hasil penelitian yang telah dilakukan didapati bahwa metode Simple Moving Average dan Single Exponential Smoothing dengan nilai interval=2 dan nilai alpha=0.2 dapat menghasilkan nilai akurasi peramalan RMSE paling baik. Dan juga didapati bahwa metode Simple Moving Average lebih unggul pada peramalan permintaan BB Glow Platinum, Eyelash Single, dan Facial Acne.
\end{abstract}

Kata kunci: Simple Moving Average, Single Exponential Smoothing, Peramalan.

\section{Decision Support System Demand Forecasting Beauty Treatment with Single Exponential Smoothing and Simple Moving Average}

\begin{abstract}
Problems of marketing strategy decisions and inventory management there are often in every company. Meanwhile in aesthetic salon, this problem can made deadstock treatment materials. This deadstock happened because of decision maker made irrational choices in inventory management, too ambitious to gain much customers as possible, but costumer confidence is low then overlaping with offers. Effect of deadstock can threaten the quality of materials then made company losses. One thing can prevent deadstock treatment materials is demand forecasting knowledge. Demand forecasting knowledge can give information about estimations of future costumer demand. Then decision maker can made best efficient choices in inventory management, so decision support system is needed. Data of demand costumer is a time-series with horizontal patterns, then the forecasting methods used in decision support system is Simple Moving Average and Single Exponential Smoothing. This decision support system is based on a web application using the object-oriented PHP programming language with Laravel framework. The results of this research that Simple Moving Average and Single Exponential Smoothing methods with an interval $=2$ and an alpha $=0.2$ can provide the best RMSE forecasting accuracy value. And Simple Moving Average was good demand forecasting method for BB Glow Platinum, Single Eyelash, and Facial Acne.
\end{abstract}

Keywords: Simple Moving Average, Single Exponential Smoothing, Forecasting. 


\section{Pendahuluan}

Pengakuan sosial masyarakat akan julukan wanita cantik merupakan kebutuhan spesifik perempuan Indonesia saat ini. Persepsi ini menjadi penggerak perilaku konsumtif pelanggan dalam memenuhi tawaran treatment kecantikan oleh penyedia layanan jasa kecantikan[1]-[4].

Perawatan kecantikan dalam bidang teknologi juga mengalami perkembangan. Hal ini menjadikan semakin bercoraknya persediaan alat dan bahan yang harus disiapkan oleh penyedia layanan jasa kecantikan. Coraknya persediaan tersebut membuat pengambilan keputusan menjadi sangat kritis[5], [6].

Pengetahuan mengenai pola permintaan yang akan datang atau sering disebut dengan peramalan permintaan dapat membantu pengambilan keputusan lebih tepat dalam menentukan prioritas persediaan dan langkah strategi penjualan. Metode dan pola data dalam peramalan yang digunakan juga berpengaruh erat terhadap keakuratan hasil peramalan. Sehingga pola data permintaan harus teridentifikasi terlebih dahulu kemudian dilakukan peramalan metode yang sesuai[7]-[10].

Adapun penelitian terkait permintaan pelanggan yang pernah dilakukan pada penjualan ayam boiler CV. Merdeka Adi Perkasa menunjukkan bahwa, nilai akurasi peramalan Simple Moving Average jauh lebih unggul daripada Trend Moment dengan RMSE sebesar 23231.09594. Dan juga penelitian penjualan obat Aknil oleh Nurul Huda Hudaningsih dkk. Bahwa metode peramalan Simple Moving Average masih tetap lebih unggul dibanding metode peramalan Single Exponential Smoothing dengan nilai RMSE sebesar 230776.9269[9], [10].

Selain itu penelitian peramalan permintaan yang pernah dilakukan oleh Rendra Gustriansyah pada produk apotek. Metode Single Exponential Smoothing lebih unggul dibanding Brown Exponential Smoothing dengan menghasilkan nilai MAPE $=1.44 \%$ yang terkategori akurasi peramalan tinggi. Dan penelitian yang dilakukan oleh Rika Safitri pada penjualan minuman kemasan PT. Coca Cola Amatil menggunakan metode Single Exponential Smoothing nilai alpha $=0.2$ dapat menghasilkan nilai akurasi $\mathrm{MAPE}=22 \%$ kategori peramalan yang proporsional[11], [12].

Pada penyedia layanan kecantikan DS Beauty and Skincare, pelaku decision maker cenderung memperhatikan pola permintaan secara sederhana tanpa bantuan perhitungan rasional apapun. Hal ini dapat mengakibatkan ancaman penimbunan persediaan bahan treatment dan kesalahan manajemen yang dapat memberikan ancaman kerugian. Sehingga decision support system sangat dibutuhkan oleh decision maker dalam menentukan pengambilan keputusan.

\section{METODOLOGI}

Penelitian ini menggunakan data sekunder berupa nota transaksi pelanggan layanan jasa kecantikan DS Beauty and Skincare selama satu tahun, dari 1 Januari 2019 sampai 31 Desember 2019. Pengembangan aplikasi menggunakan metodologi waterfall, dengan perancangan dokumentasi Unified Modeling Language, paradigma Model View Controller, dan pengujian Black Box.

\section{A. Tahapan Penelitian}

Tahapan penelitian merupakan langkah-langkah yang dilakukan pada penelitian. Setiap tahapan terdapat deliverable yang saling berkaitan dan berpengaruh pada penelitian. Adapun tahapan penelitian ini dapat dilihat pada Gambar 1 sebagai berikut:

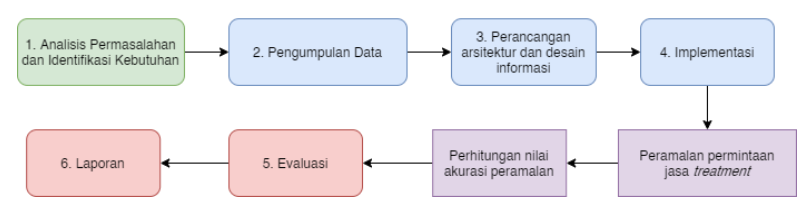

Gambar 1. Blok Diagram Tahapan Penelitian

Pada Gambar 1 tahapan penelitian dimulai dari analisis permasalahan dan identifikasi kebutuhan, lalu pengumpulan data. Dengan terkumpulnya data kemudian dilakukan perancangan arsitektur dan desain informasi. Blueprint yang telah dibuat kemudian dilakukan implementasi dan dilakukan peramalan permintaan treatment. Setelah itu terakhir adalah dilakukan perhitungan nilai akurasi model peramalan, dan evaluasi aplikasi (testing).

\section{B. Simple Moving Average}

Simple Moving Average adalah metode peramalan time series rata-rata bergerak dengan memperhatikan data terkini berdasarkan periode yang ditentukan (interval). Simple Moving Average ini berbeda dengan rata-rata sederhana (mean), yang dimana rata-rata sederhana bedasarkan data permintaan yang ada[9], [13]-[15]. Berikut persamaan metode Simple Moving Average:

$F_{t+1}=\frac{\sum A_{t}}{n}=\frac{A_{t}+A_{t-1}+\cdots+A_{t-n}}{n}$

Dimana $F_{t+1}$ mempresentasikan nilai peramalan permintaan masa yang akan datang, sementara $A_{t}$ merupakan nilai atau jumlah permintaan saat ini atau $t$ (periode yang sedang dihitung). Variabel $n$ adalah jumlah data yang digunakan atau selang waktu (interval) yang ditentukan. Maka nilai permintaan masa yang akan datang dapat diketahui dengan melakukan perhitungan rata-rata dengan jumlah permintaan dan jumlah data yang ditentukan (interval). Adapun listing program peramalan permintaan dengan metode Simple Moving Average sebagai berikut:

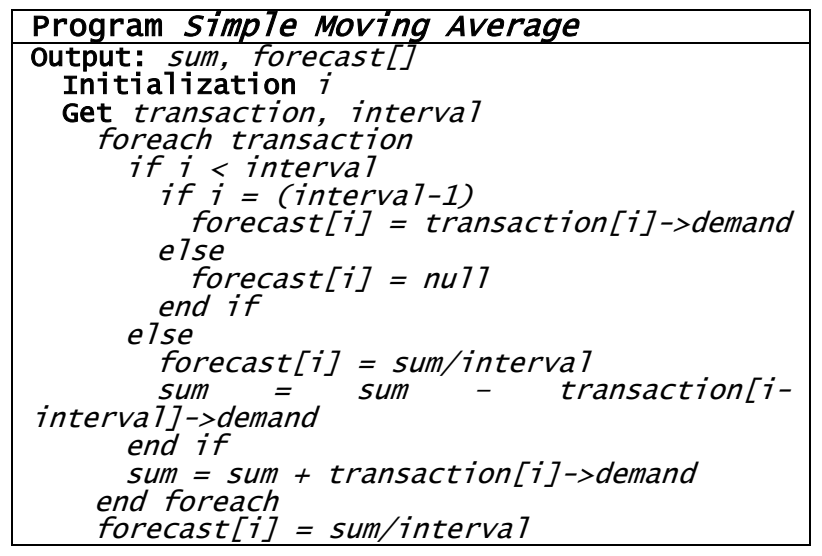




\section{Single Exponential Smoothing}

Single Exponential Smoothing adalah metode peramalan rata-rata yang terus melakukan perbaikan. Dalam metode ini data terakhir dijadikan sebagai nilai ratarata acuan kemudian menurun secara eksponensial ke periode berikutnya dan menempatkan nilai bobot yang sama pada semua data[5], [7], [10], [11], [13], [16]-[19]. Berikut persamaan metode Single Exponential Smoothing:

$F_{t+1}=a \times A_{t}+(1-a) \cdot F_{t-1}$

Dimana $F_{t+1}$ mempresentasikan nilai peramalan permintaan periode masa yang akan datang, sementara $A_{t}$ merupakan nilai atau jumlah permintaan saat ini atau $t$ (periode yang sedang dihitung). Dan variabel $a$ merupakan nilai alpha yang ditentukan. Dengan begitu nilai permintaan masa depan diketahui dengan mengalikan nilai alpha dan jumlah permintaan periode saat ini, kemudian dijumlahkan dengan nilai yang didapat dari perkalian nilai permintaan periode sebelumnya dengan 1 dikurangi nilai alpha. Adapun listing program peramalan permintaan dengan Single Exponential Smoothing sebagai berikut:

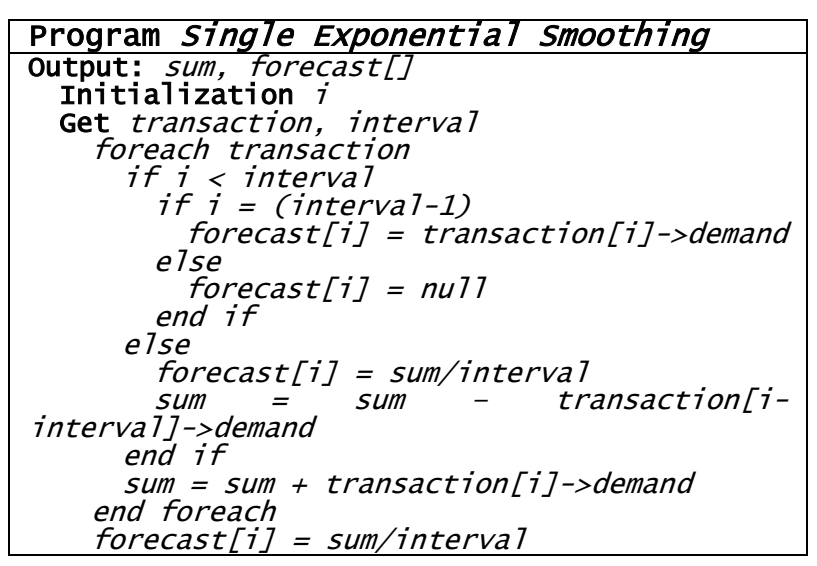

\section{Akurasi Peramalan}

Akurasi peramalan merupakan ukuran kinerja model yang dapat dijadikan tolok ukur dalam melakukan evaluasi peramalan[10], [13]. Dan tidak ada ijtimak mengenai metrik statistik paling tepat dalam menentukan akurasi peramalan. Metrik statistik mean squared error (MAE) banyak digunakan pada penelitian, namun matrik root mean squared error (RMSE) telah menjadi standar metrik statistik untuk mengukur kinerja model peramalan dalam penelitian cuaca (meteorologi). Nilai yang dihasilkan metrik statistik root mean squared error menjelaskan ukuran kinerja model secara gamblang karena dapat menunjukkan beberapa set kesalahan dengan nilai yang sama (nilai absolut), sedangkan nilai mean squared error akan bervariasi dari set ke set[20]-[22]. Berikut persamaan matrik statistik root mean squared error:

$R M S E=\sqrt{\frac{\sum(\text { error })^{2}}{n}}$

Dimana error mempresentasikan perbedaan nilai sebenarnya (aktual) dengan nilai peramalan. Kemudian menentukan nilai rata-rata nilai error yang telah dikuadratkan. Setelah itu dilakukan perhitungan akar kuadrat.

\section{E. Waterfall}

Waterfall merupakan metode pengembangan perangkat lunak dengan pendekatan hirarki dan sistematis. Dalam metode pengembangan ini perubahan dibatasi sehingga hasil identifikasi kebutuhan sangat berpengaruh pada pengembangan[23]-[26].

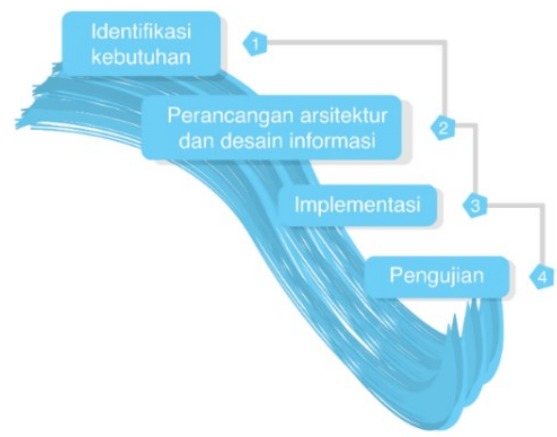

Gambar 2 Tahapan pengembangan metode Waterfall

\section{F. Unified Modeling Language.}

Unified Modeling Language merupakan kumpulan diagram dengan paradigma orientasi objek yang menggambarkan arsitektur, atribut, perilaku dengan kompleksitas yang baik dan notasi yang mudah dimengerti. Kumpulan diagram ini antara lain, use case diagram, activity diagram, sequence diagram, class diagram[27] [30].

\section{G. Model View Controller.}

Model View Controller, paradigma desain aplikasi dengan memisahkan data, logika, pengolahan data, presentasi data, dan interaksi pengguna. Lalu dikelompokkan menjadi tiga objek yaitu, model, view, controller. Sehingga hal ini membuat paradigma memiliki tingkat independensi yang kuat dan lebih fleksibel[31] [34]. Adapun pola desain Model View Controller dapat dilihat pada Gambar 3.

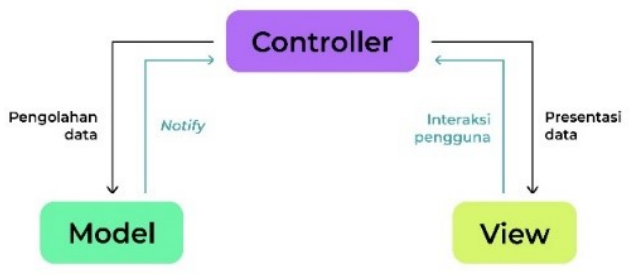

Gambar 3 Pola Desain Model View Controller

\section{H. Pengujian Black Box.}

Black Box adalah pengujian perangkat lunak yang berfokus pada fungsionalitas aplikasi. Dalam pengujian black box cenderung lebih cepat dan mudah, karena pengujian hanya dilakukan pada kesesuaian input dan output yang diharapkan[35].

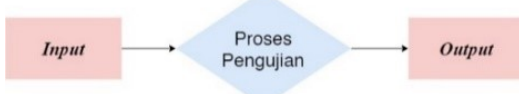

Gambar 4 Diagram Bagan Alir Pengujian Black Box 


\section{HASIL DAN PEMBAHASAN}

\section{A. Data Historik Permintaan}

Dalam nota transaksi fisik memuat beberapa informasi antara lain, menu treatment, tanggal transaksi, jumlah permintaan. Kemudian informasi yang terkandung pada nota fisik tersebut dapat menjadi data historik yang berguna dalam peramalan permintaan. Penyusunan data historik yang diperoleh dari nota fisik selama satu tahun dapat dilihat pada tabel berikut.

TABEL I

DATA Historik PERMINTAAN JASA TREATMENT KECANTIKAN

\begin{tabular}{|c|c|c|c|c|}
\hline Treatment & $\begin{array}{l}\text { BB Glow } \\
\text { Platinum }\end{array}$ & $\begin{array}{l}\text { Eyelash } \\
\text { Double } \\
\text { 2D }\end{array}$ & $\begin{array}{l}\text { Eyelash } \\
\text { Single }\end{array}$ & $\begin{array}{l}\text { Facial } \\
\text { Acne }\end{array}$ \\
\hline Jan 2019 & 38 & 18 & 32 & 10 \\
\hline Feb 2019 & 46 & 13 & 26 & 6 \\
\hline Mar 2019 & 57 & 13 & 30 & 10 \\
\hline Apr 2019 & 15 & 6 & 25 & 8 \\
\hline Mei 2019 & 26 & 9 & 24 & 2 \\
\hline Jun 2019 & 25 & 6 & 24 & 5 \\
\hline Jul 2019 & 30 & 2 & 8 & 3 \\
\hline Agt 2019 & 17 & 5 & 16 & 7 \\
\hline Sep 2019 & 17 & 5 & 11 & 4 \\
\hline Okt 2019 & 28 & 5 & 10 & 10 \\
\hline Nov 2019 & 18 & 9 & 17 & 6 \\
\hline Des 2019 & 25 & 9 & 20 & 4 \\
\hline
\end{tabular}

B. Perancangan Arsitektur dan Desain Informasi

Perancangan arsitektur dan desain informasi pada penelitian ini menggunakan Unified Modeling Language (UML), model yang secara spesifik berorientasi objek.

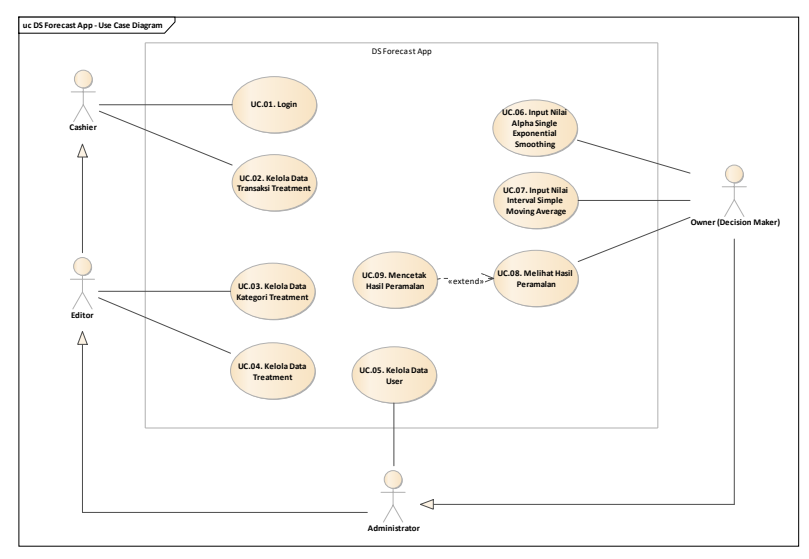

Gambar 5 Diagram Use Case

Pada Gambar 5 didapati bahwa ada empat aktor pengguna aplikasi pendukung keputusan yaitu, cashier, editor, administrator, dan owner atau decision maker. Setiap aktor memiliki aktivitas dan wewenang bermacammacam. Sehingga didapati penomoran hak akses atau role id sebagai berikut:

- Cashier, memiliki hak akses low-user.

- Editor, memiliki hak akses mid-user.

- Administrator, memiliki hak akses top-user.

- Owner/Decision Maker, memiliki hak akses owneronly.
TABEL III

DEFINISI USE CASE

\begin{tabular}{|c|l|l|}
\hline$\#$ & Use Case & Definisi \\
\hline 1 & Login & Proses autentikasi pada aplikasi. \\
\hline 2 & $\begin{array}{l}\text { Kelola Data } \\
\text { Transaksi } \\
\text { Treatment }\end{array}$ & $\begin{array}{l}\text { Melakukan manajemen kelola (tambah, } \\
\text { ubah, dan hapus) data transaksi } \\
\text { treatment. }\end{array}$ \\
\hline 3 & $\begin{array}{l}\text { Kelola Data } \\
\text { Kategori } \text { Treatment }\end{array}$ & $\begin{array}{l}\text { Melakukan manajemen kelola (tambah, } \\
\text { ubah, dan hapus) data kategori } \\
\text { treatment. }\end{array}$ \\
\hline 4 & $\begin{array}{l}\text { Kelola Data } \\
\text { Treatment }\end{array}$ & $\begin{array}{l}\text { Melakukan manajemen kelola (tambah, } \\
\text { ubah, dan hapus) data menu treatment. }\end{array}$ \\
\hline 5 & Kelola Data User & $\begin{array}{l}\text { Melakukan manajemen kelola (tambah, } \\
\text { ubah, dan hapus) data pengguna. }\end{array}$ \\
\hline 6 & Input Nilai Alpha & Mengubah nilai alpha. \\
\hline 7 & Input Nilai Interval & Mengubah nilai interval. \\
\hline 8 & $\begin{array}{l}\text { Melihat Hasil } \\
\text { Peramalan }\end{array}$ & $\begin{array}{l}\text { Melihat hasil peramalan metode Single } \\
\text { Moving Average dan Single Exponential } \\
\text { Smoothing. }\end{array}$ \\
\hline 9 & $\begin{array}{l}\text { Mencetak Hasil } \\
\text { Peramalan }\end{array}$ & $\begin{array}{l}\text { Mencetak hasil peramalan atau } \\
\text { melakukan konversi halaman web } \\
\text { kedalam laporan. }\end{array}$ \\
\hline
\end{tabular}

Dengan tersusunnya definisi use case beserta aktor pengguna aplikasi pendukung keputusan peramalan permintaan treatment kecantikan. Sehingga dapat didapati class diagram sebagai berikut.

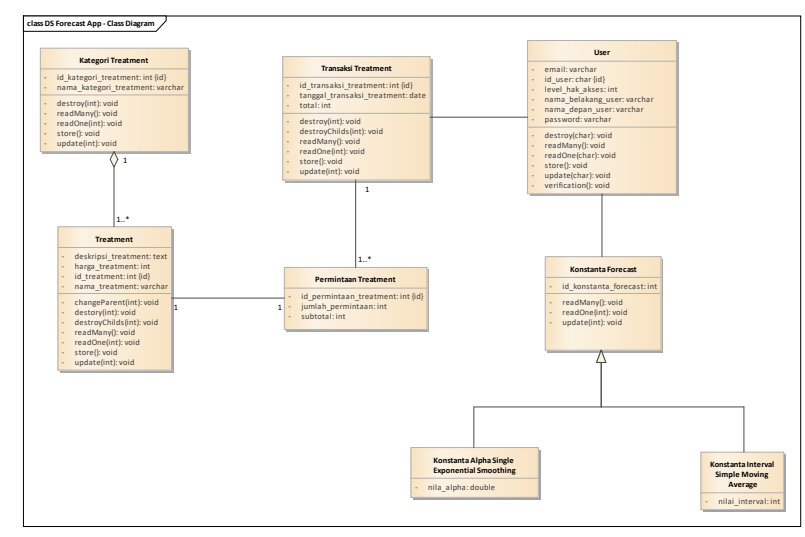

Gambar 6 Diagram Class Diagram

Pada Gambar 6 terdapat beberapa class yang terdiri dari, user, kategori treatment, treatment, permintaan treatment, transaksi treatment, konstanta forecast, konstanta alpha single exponential smoothing, dan konstanta interval simple moving average. Di dalam setiap class tersebut terdapat atribut dan proses atau method.

\section{Peramalan Permintaan BB Glow Platinum}

Permintaan treatment BB Glow Platinum berdasarkan data historik ada pada Tabel I, data permintaan selama satu tahun tersebut dilakukan perhitungan peramalan menggunakan metode Simple Moving Average. Perhitungan peramalan ini dilakukan secara berturut-turut dengan menggunakan nilai interval yang berbeda, dimulai dari dua sampai delapan. Hal ini guna mencari nilai interval yang paling baik dalam melakukan peramalan permintaan BB Glow Platinum. Hasil perhitungan peramalan permintaan BB Glow Platinum dengan Simple Moving Average dapat dilihat pada tabel berikut. 
TABEL IIIII

Hasil Perhitungan Peramalan PermintaAn BB Glow Platinum DENGAN SIMPLE MOVING AVERAGE

\begin{tabular}{|c|c|l|l|l|l|l|l|l|}
\hline Interval & $\#$ & $\mathbf{2}$ & $\mathbf{3}$ & $\mathbf{4}$ & $\mathbf{5}$ & $\mathbf{6}$ & $\mathbf{7}$ & $\mathbf{8}$ \\
\hline Jan 2019 & 38 & & & & & & & \\
\hline Feb 2019 & 46 & & & & & & & \\
\hline $\begin{array}{c}\text { Mar } \\
2019\end{array}$ & 57 & 42 & & & & & & \\
\hline Apr 2019 & 15 & 51.5 & 47 & & & & & \\
\hline Mei 2019 & 26 & 36 & 39.3 & 39 & & & & \\
\hline Jun 2019 & 25 & 20.5 & 32.7 & 36 & 36.4 & & & \\
\hline Jul 2019 & 30 & 22.5 & 22 & 30.8 & 33.8 & 34.5 & & \\
\hline Agt 2019 & 17 & 27.5 & 27 & 24 & 30.6 & 33.2 & 33.9 & \\
\hline Sep 2019 & 17 & 23.5 & 24 & 24.5 & 22.6 & 28.3 & 30.9 & 31.8 \\
\hline Okt 2019 & 28 & 17 & 21.3 & 22.3 & 23 & 21.7 & 26.7 & 29.1 \\
\hline $\begin{array}{c}\text { Nov } \\
2019\end{array}$ & 18 & 22.5 & 20.7 & 23 & 23.4 & 23.8 & 22.6 & 26.9 \\
\hline Des 2019 & 25 & 23 & 21 & 20 & 22 & 22.5 & 23 & 22 \\
\hline
\end{tabular}

Selanjutnya dilakukan perhitungan peramalan metode Single Exponential Smoothing dengan nilai alpha mulai dari 0.1 sampai 0.9. Hasil perhitungan peramalan BB Glow Platinum dengan Single Exponential Smoothing dapat dilihat pada Tabel IV.

TABEL IV

Hasil Perhitungan Peramalan Permintaan BB Glow Platinum DENGAN SINGLE EXPONENTIAL SMOOTHING

\begin{tabular}{|c|c|c|c|c|c|c|c|c|c|c|}
\hline $\begin{array}{c}\text { Alp } \\
\text { ha } \\
\end{array}$ & \# & $\begin{array}{l}0 . \\
1\end{array}$ & $\begin{array}{l}0 . \\
2\end{array}$ & $\begin{array}{l}0 . \\
3 \\
\end{array}$ & $\begin{array}{l}0 . \\
4 \\
\end{array}$ & $\begin{array}{l}0 . \\
5\end{array}$ & $\begin{array}{l}0 . \\
6\end{array}$ & $\begin{array}{l}0 . \\
7 \\
\end{array}$ & $\begin{array}{l}0 . \\
8\end{array}$ & $\begin{array}{l}0 . \\
9 \\
\end{array}$ \\
\hline $\begin{array}{c}\text { Jan } \\
201 \\
9 \\
\end{array}$ & $\begin{array}{l}3 \\
8\end{array}$ & & & & & & & & & \\
\hline $\begin{array}{c}\text { Feb } \\
201 \\
9\end{array}$ & $\begin{array}{l}4 \\
6\end{array}$ & & & & & & & & & \\
\hline $\begin{array}{c}\text { Mar } \\
201 \\
9\end{array}$ & $\begin{array}{l}5 \\
7\end{array}$ & 46 & 46 & 46 & 46 & 46 & 46 & 46 & 46 & 46 \\
\hline $\begin{array}{c}\text { Apr } \\
201 \\
9\end{array}$ & $\begin{array}{l}1 \\
5\end{array}$ & $\begin{array}{l}55 . \\
9\end{array}$ & $\begin{array}{l}54 . \\
8\end{array}$ & $\begin{array}{l}53 . \\
7\end{array}$ & $\begin{array}{l}52 . \\
6\end{array}$ & $\begin{array}{l}51 . \\
5\end{array}$ & $\begin{array}{l}50 . \\
4\end{array}$ & $\begin{array}{l}49 . \\
3\end{array}$ & $\begin{array}{l}48 . \\
2\end{array}$ & $\begin{array}{l}47 . \\
1\end{array}$ \\
\hline $\begin{array}{c}\text { Mei } \\
201 \\
9\end{array}$ & $\begin{array}{l}2 \\
6\end{array}$ & $\begin{array}{l}19 . \\
1\end{array}$ & $\begin{array}{l}22 . \\
96\end{array}$ & $\begin{array}{l}26 . \\
61\end{array}$ & $\begin{array}{l}30 . \\
04\end{array}$ & $\begin{array}{l}33 . \\
25\end{array}$ & $\begin{array}{l}36 . \\
24\end{array}$ & $\begin{array}{l}39 . \\
01\end{array}$ & $\begin{array}{l}41 . \\
56\end{array}$ & $\begin{array}{l}43 . \\
89\end{array}$ \\
\hline $\begin{array}{c}\text { Jun } \\
201 \\
9\end{array}$ & $\begin{array}{l}2 \\
5\end{array}$ & $\begin{array}{l}25 . \\
39\end{array}$ & $\begin{array}{l}26 . \\
18\end{array}$ & $\begin{array}{l}27 . \\
61\end{array}$ & $\begin{array}{l}29 . \\
62\end{array}$ & $\begin{array}{l}32 . \\
14\end{array}$ & $\begin{array}{l}35 . \\
1\end{array}$ & $\begin{array}{l}38 . \\
44\end{array}$ & $\begin{array}{l}42 . \\
1\end{array}$ & $\begin{array}{l}25 . \\
3\end{array}$ \\
\hline $\begin{array}{c}\text { Jul } \\
201 \\
9 \\
\end{array}$ & $\begin{array}{l}3 \\
0\end{array}$ & $\begin{array}{l}25 . \\
03\end{array}$ & $\begin{array}{l}25 . \\
07\end{array}$ & $\begin{array}{l}25 . \\
35\end{array}$ & $\begin{array}{l}26 . \\
04\end{array}$ & $\begin{array}{l}27 . \\
31\end{array}$ & $\begin{array}{l}29 . \\
28\end{array}$ & $\begin{array}{l}32 . \\
07\end{array}$ & $\begin{array}{l}35 . \\
75\end{array}$ & $\begin{array}{l}40 . \\
39\end{array}$ \\
\hline $\begin{array}{c}\text { Agt } \\
201 \\
9\end{array}$ & $\begin{array}{l}1 \\
7\end{array}$ & $\begin{array}{l}29 . \\
5\end{array}$ & $\begin{array}{l}29 . \\
01\end{array}$ & $\begin{array}{l}28 . \\
6\end{array}$ & $\begin{array}{l}28 . \\
41\end{array}$ & $\begin{array}{l}28 . \\
65\end{array}$ & $\begin{array}{l}29 . \\
57\end{array}$ & $\begin{array}{l}31 . \\
45\end{array}$ & $\begin{array}{l}34 . \\
6\end{array}$ & $\begin{array}{l}39 . \\
35\end{array}$ \\
\hline $\begin{array}{c}\text { Sep } \\
201 \\
9 \\
\end{array}$ & $\begin{array}{l}1 \\
7\end{array}$ & $\begin{array}{l}18 . \\
25\end{array}$ & $\begin{array}{l}19 . \\
4\end{array}$ & $\begin{array}{l}20 . \\
48\end{array}$ & $\begin{array}{l}21 . \\
56\end{array}$ & $\begin{array}{l}22 . \\
82\end{array}$ & $\begin{array}{l}24 . \\
54\end{array}$ & $\begin{array}{l}27 . \\
11\end{array}$ & $\begin{array}{l}31 . \\
08\end{array}$ & $\begin{array}{l}37 . \\
11\end{array}$ \\
\hline $\begin{array}{c}\text { Okt } \\
201 \\
9\end{array}$ & $\begin{array}{l}2 \\
8\end{array}$ & $\begin{array}{l}17 . \\
12\end{array}$ & $\begin{array}{l}17 . \\
48\end{array}$ & $\begin{array}{l}18 . \\
04\end{array}$ & $\begin{array}{l}18 . \\
82\end{array}$ & $\begin{array}{l}19 . \\
91\end{array}$ & $\begin{array}{l}21 . \\
52\end{array}$ & $\begin{array}{l}24 . \\
08\end{array}$ & $\begin{array}{l}28 \\
26\end{array}$ & $\begin{array}{l}35 . \\
1\end{array}$ \\
\hline $\begin{array}{c}\text { Nov } \\
201 \\
9 \\
\end{array}$ & $\begin{array}{l}1 \\
8\end{array}$ & $\begin{array}{l}26 . \\
91\end{array}$ & $\begin{array}{l}25 . \\
89\end{array}$ & $\begin{array}{l}25 . \\
01\end{array}$ & $\begin{array}{l}24 . \\
33\end{array}$ & $\begin{array}{l}23 . \\
95\end{array}$ & $\begin{array}{l}24 . \\
11\end{array}$ & $\begin{array}{l}25 . \\
25\end{array}$ & $\begin{array}{l}28 . \\
21\end{array}$ & $\begin{array}{l}34 . \\
39\end{array}$ \\
\hline $\begin{array}{c}\text { Des } \\
201 \\
9\end{array}$ & $\begin{array}{l}2 \\
5\end{array}$ & $\begin{array}{l}18 . \\
89\end{array}$ & $\begin{array}{l}19 . \\
57\end{array}$ & $\begin{array}{l}20 . \\
1\end{array}$ & $\begin{array}{l}20 . \\
53\end{array}$ & $\begin{array}{l}20 . \\
97\end{array}$ & $\begin{array}{l}21 . \\
66\end{array}$ & $\begin{array}{l}23 . \\
08\end{array}$ & $\begin{array}{l}26 . \\
17\end{array}$ & $\begin{array}{l}32 . \\
75\end{array}$ \\
\hline
\end{tabular}

Setelah dilakukan perhitungan peramalan permintaan treatment BB Glow Platinum dengan Simple Moving Average dan Single Exponential Smoothing. Kemudian dilakukan perhitungan akurasi peramalan pada kedua metode tersebut. Hasil perhitungan akurasi peramalan permintaan BB Glow Platinum dengan Simple Moving Average dan Single Exponential Smoothing dapat dilihat pada tabel sebagai berikut.

TABEL V

Hasil Perhitungan Akurasi Peramalan Permintaan BB Glow PLATINUM DENGAN SIMPLE MOVING AVERAGE

\begin{tabular}{|l|c|c|c|c|c|c|c|}
\hline $\begin{array}{l}\text { Interv } \\
\text { al }\end{array}$ & $\mathbf{2}$ & $\mathbf{3}$ & $\mathbf{4}$ & $\mathbf{5}$ & $\mathbf{6}$ & $\mathbf{7}$ & $\mathbf{8}$ \\
\hline RMSE & $\begin{array}{c}14.1 \\
26\end{array}$ & $\begin{array}{c}171 . \\
23\end{array}$ & $\begin{array}{c}795 . \\
35\end{array}$ & $\begin{array}{c}782 . \\
15\end{array}$ & $\begin{array}{c}772 . \\
79\end{array}$ & $\begin{array}{c}770 . \\
11\end{array}$ & $\begin{array}{c}765.6 \\
48\end{array}$ \\
\hline
\end{tabular}

Pada hasil perhitungan akurasi peramalan Tabel V, didapati bahwa metode peramalan Simple Moving Average pada treatment $\mathrm{BB}$ Glow Platinum dengan nilai interval $=2$ merupakan nilai interval yang paling baik. Hal ini karena nilai interval tersebut dapat menghasilkan rata-rata kesalahan paling kecil, yaitu 14.12621676 atau 14.126.

\section{TABEL VI}

Hasil Perhitungan Akurasi Peramalan Permintaan BB Glow PLATINUM DENGAN SINGLE EXPONENTIAL SMOOTHING

\begin{tabular}{|c|c|c|c|c|c|c|c|c|c|}
\hline $\begin{array}{l}\text { Alp } \\
\text { ha }\end{array}$ & $\mathbf{0 . 1}$ & $\mathbf{0 . 2}$ & $\mathbf{0 . 3}$ & $\mathbf{0 . 4}$ & $\mathbf{0 . 5}$ & $\mathbf{0 . 6}$ & $\mathbf{0 . 7}$ & $\mathbf{0 . 8}$ & $\mathbf{0 .}$ \\
\hline RM & 15. & 14. & 31. & 31. & 32. & 32. & 34. & 36. & 40 \\
SE & 03 & 46 & 03 & 41 & 02 & 94 & 36 & 56 & .1 \\
\hline
\end{tabular}

Sedangkan hasil perhitungan akurasi peramalan BB Glow Platinum dengan metode Single Exponential Smoothing pada Tabel VI, didapati bahwa peramalan dengan nilai alpha $=0.2$ dapat menghasilkan nilai akurasi yang paling baik yaitu, 14.46098144 .

\section{Peramalan Permintaan Eyelash Double 2D}

Permintaan Eyelash Double 2D berdasarkan data historik ada pada Tabel I, data tersebut dilakukan peramalan Simple Moving Average dengan nilai interval mulai dari dua sampai delapan. Hasil perhitungan peramalan permintaan dapat dilihat pada tabel berikut.

TABEL VIVI

Hasil Perhitungan Peramalan Permintaan Eyelash Double 2D DENGAN SIMPLE MOVING AVERAGE

\begin{tabular}{|c|l|l|l|l|l|l|l|c|}
\hline Interval & $\#$ & $\mathbf{2}$ & $\mathbf{3}$ & $\mathbf{4}$ & $\mathbf{5}$ & $\mathbf{6}$ & $\mathbf{7}$ & $\mathbf{8}$ \\
\hline Jan 2019 & 18 & & & & & & & \\
\hline Feb 2019 & 13 & & & & & & & \\
\hline $\begin{array}{c}\text { Mar } \\
2019\end{array}$ & 13 & 15.5 & & & & & & \\
\hline Apr 2019 & 6 & 13 & 14.7 & & & & & \\
\hline Mei 2019 & 9 & 9.5 & 10.7 & 12.5 & & & & \\
\hline Jun 2019 & 6 & 7.5 & 9.3 & 10.3 & 11.8 & & & \\
\hline Jul 2019 & 2 & 7.5 & 7 & 8.5 & 9.4 & 10.8 & & \\
\hline Agt 2019 & 5 & 4 & 5.7 & 5.8 & 7.2 & 8.17 & 9.57 & \\
\hline Sep 2019 & 5 & 3.5 & 4.3 & 5.5 & 5.6 & 6.83 & 7.71 & 9 \\
\hline Okt 2019 & 5 & 5 & 4 & 4.5 & 5.4 & 5.5 & 6.57 & 7.38 \\
\hline $\begin{array}{c}\text { Nov } \\
2019\end{array}$ & 9 & 5 & 5 & 4.3 & 4.6 & 5.33 & 5.43 & 6.38 \\
\hline Des 2019 & 9 & 7 & 6.3 & 6 & 5.2 & 5.33 & 5.86 & 5.88 \\
\hline
\end{tabular}


Selanjutnya dilakukan perhitungan peramalan dengan metode Single Exponential Smoothing dengan nilai alpha mulai dari 0.1 sampai 0.9 . Hasil perhitungan peramalan Eyelash Double 2D dengan Single Exponential Smoothing dapat dilihat pada Tabel VIII.

TABEL VIII

Hasil Perhitungan Peramalan Permintaan BB Glow Platinum DENGAN SINGLE EXPONENTIAL SMOOTHING

\begin{tabular}{|c|c|c|c|c|c|c|c|c|c|c|}
\hline $\begin{array}{c}\text { Alp } \\
\text { ha }\end{array}$ & \# & $\begin{array}{l}0 . \\
1\end{array}$ & $\begin{array}{l}0 . \\
2\end{array}$ & $\begin{array}{l}0 . \\
3 \\
\end{array}$ & $\begin{array}{l}0 . \\
4\end{array}$ & $\begin{array}{l}0 . \\
5\end{array}$ & $\begin{array}{l}0 . \\
6\end{array}$ & $\begin{array}{l}0 . \\
7\end{array}$ & $\begin{array}{l}0 . \\
8\end{array}$ & $\begin{array}{l}0 . \\
9 \\
\end{array}$ \\
\hline $\begin{array}{c}\text { Jan } \\
201 \\
9 \\
\end{array}$ & $\begin{array}{l}1 \\
8\end{array}$ & & & & & & & & & \\
\hline $\begin{array}{c}\text { Feb } \\
201 \\
9 \\
\end{array}$ & $\begin{array}{l}1 \\
3\end{array}$ & & & & & & & & & \\
\hline $\begin{array}{c}\text { Mar } \\
201 \\
9\end{array}$ & $\begin{array}{l}1 \\
3\end{array}$ & 13 & 13 & 13 & 13 & 13 & 13 & 13 & 13 & 13 \\
\hline $\begin{array}{c}\text { Apr } \\
201 \\
9\end{array}$ & 6 & 13 & 13 & 13 & 13 & 13 & 13 & 13 & 13 & 13 \\
\hline $\begin{array}{c}\text { Mei } \\
201 \\
9\end{array}$ & 9 & 6.7 & 7.4 & 8.1 & 8.8 & 9.5 & $\begin{array}{c}10 . \\
2\end{array}$ & $\begin{array}{c}10 . \\
9\end{array}$ & $\begin{array}{c}11 . \\
6\end{array}$ & $\begin{array}{c}12 . \\
3\end{array}$ \\
\hline $\begin{array}{c}\text { Jun } \\
201 \\
9 \\
\end{array}$ & 6 & $\begin{array}{c}8.7 \\
7\end{array}$ & $\begin{array}{c}8.6 \\
8\end{array}$ & $\begin{array}{c}8.7 \\
3\end{array}$ & $\begin{array}{c}8.9 \\
2\end{array}$ & $\begin{array}{c}9.2 \\
5\end{array}$ & $\begin{array}{c}9.7 \\
2\end{array}$ & $\begin{array}{l}10 . \\
33\end{array}$ & $\begin{array}{l}11 . \\
08\end{array}$ & $\begin{array}{l}11 . \\
97\end{array}$ \\
\hline $\begin{array}{c}\text { Jul } \\
201 \\
9\end{array}$ & 2 & $\begin{array}{l}6.2 \\
77\end{array}$ & $\begin{array}{l}6.5 \\
36\end{array}$ & $\begin{array}{l}6.8 \\
19\end{array}$ & $\begin{array}{l}7.1 \\
68\end{array}$ & $\begin{array}{l}7.6 \\
25\end{array}$ & $\begin{array}{l}8.2 \\
32\end{array}$ & $\begin{array}{l}9.0 \\
31\end{array}$ & $\begin{array}{l}10 . \\
06\end{array}$ & $\begin{array}{l}11 . \\
37\end{array}$ \\
\hline $\begin{array}{c}\text { Agt } \\
201 \\
9\end{array}$ & 5 & $\begin{array}{l}2.4 \\
27\end{array}$ & $\begin{array}{l}2.9 \\
07\end{array}$ & $\begin{array}{l}3.4 \\
45\end{array}$ & $\begin{array}{l}4.0 \\
67\end{array}$ & $\begin{array}{c}4.8 \\
12\end{array}$ & $\begin{array}{l}5.7 \\
39\end{array}$ & $\begin{array}{l}6.9 \\
21\end{array}$ & $\begin{array}{l}8.4 \\
51\end{array}$ & $\begin{array}{l}10 . \\
44\end{array}$ \\
\hline $\begin{array}{c}\text { Sep } \\
201 \\
9\end{array}$ & 5 & $\begin{array}{l}4.7 \\
42\end{array}$ & $\begin{array}{l}4.5 \\
81\end{array}$ & $\begin{array}{l}4.5 \\
33\end{array}$ & $\begin{array}{l}4.6 \\
26\end{array}$ & $\begin{array}{l}4.9 \\
06\end{array}$ & $\begin{array}{l}5.4 \\
43\end{array}$ & $\begin{array}{l}6.3 \\
45\end{array}$ & $\begin{array}{c}7.7 \\
6\end{array}$ & $\begin{array}{l}9.8 \\
92\end{array}$ \\
\hline $\begin{array}{c}\text { Okt } \\
201 \\
9 \\
\end{array}$ & 5 & $\begin{array}{r}4.9 \\
74\end{array}$ & $\begin{array}{r}4.9 \\
16\end{array}$ & $\begin{array}{c}4.8 \\
6\end{array}$ & $\begin{array}{c}4.8 \\
5\end{array}$ & $\begin{array}{l}4.9 \\
53\end{array}$ & $\begin{array}{l}5.2 \\
66\end{array}$ & $\begin{array}{l}5.9 \\
41\end{array}$ & $\begin{array}{l}7.2 \\
08\end{array}$ & $\begin{array}{c}9.4 \\
02\end{array}$ \\
\hline $\begin{array}{c}\text { Nov } \\
201 \\
9 \\
\end{array}$ & 9 & $\begin{array}{l}4.9 \\
97\end{array}$ & $\begin{array}{l}4.9 \\
83\end{array}$ & $\begin{array}{c}4.9 \\
58\end{array}$ & $\begin{array}{c}4.9 \\
4\end{array}$ & $\begin{array}{l}4.9 \\
76\end{array}$ & $\begin{array}{l}5.1 \\
59\end{array}$ & $\begin{array}{c}5.6 \\
59\end{array}$ & $\begin{array}{l}6.7 \\
67\end{array}$ & $\begin{array}{l}8.9 \\
62\end{array}$ \\
\hline $\begin{array}{c}\text { Des } \\
201 \\
9\end{array}$ & 9 & $\begin{array}{l}8.5 \\
99\end{array}$ & $\begin{array}{l}8.1 \\
96\end{array}$ & $\begin{array}{l}7.7 \\
87\end{array}$ & $\begin{array}{l}7.3 \\
76\end{array}$ & $\begin{array}{l}6.9 \\
88\end{array}$ & $\begin{array}{l}6.6 \\
95\end{array}$ & $\begin{array}{l}6.6 \\
61\end{array}$ & $\begin{array}{l}7.2 \\
13\end{array}$ & $\begin{array}{l}8.9 \\
66\end{array}$ \\
\hline
\end{tabular}

Setelah dilakukan peramalan Simple Moving Average dan Single Exponential Smoothing, kemudian dilakukan perhitungan akurasi peramalan pada hasil peramalan permintaan kedua metode tersebut. Hasil perhitungan akurasi peramalan permintaan Eyelash Double 2D dengan Simple Moving Average dapat dilihat pada tabel berikut.

\section{TABEL IX}

Hasil Perhitungan Akurasi Peramalan Permintaan Eyelash DOUBLE 2D DENGAN SIMPLE MOVING AVERAGE

\begin{tabular}{|c|c|c|c|c|c|c|c|}
\hline $\begin{array}{l}\text { Inter } \\
\text { val }\end{array}$ & 2 & 3 & 4 & 5 & 6 & 7 & 8 \\
\hline $\begin{array}{c}\text { RMS } \\
\text { E }\end{array}$ & $\begin{array}{l}3.335 \\
41\end{array}$ & $\begin{array}{l}15.44 \\
44\end{array}$ & $\begin{array}{l}58.89 \\
84\end{array}$ & $\begin{array}{l}55.45 \\
14\end{array}$ & $\begin{array}{l}52.98 \\
14\end{array}$ & $\begin{array}{l}51.61 \\
63\end{array}$ & $\begin{array}{l}52.63 \\
67\end{array}$ \\
\hline
\end{tabular}

Pada hasil perhitungan akurasi peramalan Tabel IX, didapati bahwa peramalan Simple Moving Average dengan nilai interval $=2$ dapat menghasilkan nilai akurasi yang paling baik yaitu, 3.33541. Sedangkan hasil perhitungan akurasi peramalan Single Exponential Smoothing dapat dilihat pada Tabel X.

TABEL X

Hasil Perhitungan AKuRasi Peramalan PermintaAn Eyelash DOUBLE 2D DENGAN SINGLE EXPONENTIAL SMOOTHING

\begin{tabular}{|l|c|c|c|c|c|c|c|c|c|}
\hline $\begin{array}{l}\text { Al } \\
\text { ph } \\
\text { a }\end{array}$ & $\mathbf{0 . 1}$ & $\mathbf{0 . 2}$ & $\mathbf{0 . 3}$ & $\mathbf{0 . 4}$ & $\mathbf{0 . 5}$ & $\mathbf{0 . 6}$ & $\mathbf{0 . 7}$ & $\mathbf{0 . 8}$ & $\mathbf{0 . 9}$ \\
\hline RM & 3.2 & 3.1 & 8.1 & 8.2 & 8.4 & 8.7 & 9.1 & 9.8 & 11. \\
SE & 112 & 726 & 706 & 866 & 694 & 523 & 921 & 896 & 035 \\
\hline
\end{tabular}

Pada hasil perhitungan akurasi peramalan Tabel X, didapati bahwa peramalan Single Exponential Smoothing dengan nilai alpha $=0.2$ dapat menghasilkan nilai akurasi yang paling baik yaitu, 3.1726.

\section{E. Peramalan Permintaan Eyelash Single}

Permintaan Eyelash Single berdasarkan data historik ada pada Tabel I, data permintaan tersebut kemudian dilakukan peramalan Simple Moving Average dengan nilai interval mulai dari dua sampai delapan. Hasil perhitungan peramalan permintaan dapat dilihat pada tabel sebagai berikut.

TABEL XI

Hasil Perhitungan Peramalan PermintaAn Eyelash SingLE DENGAN SIMPLE MOVING AVERAGE

\begin{tabular}{|c|c|c|c|c|c|c|c|c|}
\hline Interval & $\#$ & $\mathbf{2}$ & $\mathbf{3}$ & $\mathbf{4}$ & $\mathbf{5}$ & $\mathbf{6}$ & $\mathbf{7}$ & $\mathbf{8}$ \\
\hline Jan 2019 & 32 & & & & & & & \\
\hline Feb 2019 & 26 & & & & & & & \\
\hline $\begin{array}{c}\text { Mar } \\
2019\end{array}$ & 30 & 29 & & & & & & \\
\hline Apr 2019 & 25 & 28 & 29.3 & & & & & \\
\hline Mei 2019 & 24 & 27.5 & 27 & 28.3 & & & & \\
\hline Jun 2019 & 24 & 24.5 & 26.3 & 26.3 & 27.4 & & & \\
\hline Jul 2019 & 8 & 24 & 24.3 & 25.8 & 25.8 & 26.8 & & \\
\hline Agt 2019 & 16 & 16 & 18.7 & 20.3 & 22.2 & 22.8 & 24.1 & \\
\hline Sep 2019 & 11 & 12 & 16 & 18 & 19.4 & 21.2 & 21.9 & 23.1 \\
\hline Okt 2019 & 10 & 13.5 & 11.7 & 14.8 & 16.6 & 18 & 19.7 & 20.5 \\
\hline $\begin{array}{c}\text { Nov } \\
\text { 2019 }\end{array}$ & 17 & 10.5 & 12.3 & 11.3 & 13.8 & 15.5 & 16.9 & 18.5 \\
\hline Des 2019 & 20 & 13.5 & 12.7 & 13.5 & 12.4 & 14.3 & 15.7 & 16.9 \\
\hline
\end{tabular}

Kemudian dilakukan perhitungan akurasi peramalan pada hasil peramalan Tabel XI. Hasil perhitungan akurasi peramalan permintaan Eyelash Single dengan Simple Moving Average dapat dilihat pada tabel berikut.

TABEL XII

Hasil Perhitungan AKURASi PERAMALAN PERmintaAn EYELASH Double 2D DENGan Simple MoVING AVERAGE

\begin{tabular}{|c|c|c|c|c|c|c|c|}
\hline $\begin{array}{l}\text { Inter } \\
\text { val }\end{array}$ & $\mathbf{2}$ & $\mathbf{3}$ & $\mathbf{4}$ & $\mathbf{5}$ & $\mathbf{6}$ & $\mathbf{7}$ & $\mathbf{8}$ \\
\hline $\begin{array}{c}\text { RMS } \\
\text { E }\end{array}$ & $\begin{array}{c}6.13 \\
39\end{array}$ & $\begin{array}{c}45.6 \\
049\end{array}$ & $\begin{array}{c}426.3 \\
281\end{array}$ & $\begin{array}{c}415.0 \\
514\end{array}$ & $\begin{array}{c}409.8 \\
518\end{array}$ & $\begin{array}{c}396.0 \\
734\end{array}$ & $\begin{array}{c}395.5 \\
078\end{array}$ \\
\hline
\end{tabular}

Pada hasil perhitungan akurasi peramalan Tabel XII, didapati bahwa peramalan Simple Moving Average pada treatment Eyelash Single dengan nilai interval $=2$ merupakan nilai interval yang paling baik yaitu, 6.1339 . 
Selanjutnya dilakukan perhitungan peramalan metode Single Exponential Smoothing dengan nilai alpha mulai dari 0.1 sampai 0.9. Hasil peramalan permintaan Eyelash Single dengan Single Exponential Smoothing dapat dilihat pada tabel berikut.

TABEL XIII

Hasil Perhitungan Peramalan Permintaan Eyelash Single DENGAN SINGLE EXPONENTIAL SMOOTHING

\begin{tabular}{|c|c|c|c|c|c|c|c|c|c|c|}
\hline $\begin{array}{c}\text { Al } \\
\text { ph } \\
\text { a }\end{array}$ & $\#$ & $\begin{array}{l}0 . \\
1\end{array}$ & $\begin{array}{l}0 . \\
2\end{array}$ & $\begin{array}{l}0 . \\
3\end{array}$ & $\begin{array}{l}0 . \\
4\end{array}$ & $\begin{array}{l}\text { 0. } \\
5\end{array}$ & $\begin{array}{c}0 . \\
6\end{array}$ & $\begin{array}{l}0 . \\
7\end{array}$ & 0.8 & 0.9 \\
\hline $\begin{array}{c}\text { Jan } \\
201 \\
9\end{array}$ & $\begin{array}{l}3 \\
2\end{array}$ & & & & & & & & & \\
\hline $\begin{array}{c}\text { Feb } \\
201 \\
9\end{array}$ & $\begin{array}{l}2 \\
6\end{array}$ & & & & & & & & & \\
\hline $\begin{array}{c}\text { Mar } \\
201 \\
9\end{array}$ & $\begin{array}{l}3 \\
0\end{array}$ & 26 & 26 & 26 & 26 & 26 & 26 & 26 & 26 & 26 \\
\hline $\begin{array}{c}\text { Apr } \\
201 \\
9\end{array}$ & $\begin{array}{l}2 \\
5\end{array}$ & $\begin{array}{c}29 . \\
6\end{array}$ & $\begin{array}{c}29 . \\
2\end{array}$ & $\begin{array}{c}28 . \\
8\end{array}$ & $\begin{array}{c}28 . \\
4\end{array}$ & 28 & $\begin{array}{c}27 . \\
6\end{array}$ & $\begin{array}{c}27 . \\
2\end{array}$ & $\begin{array}{c}26 . \\
8\end{array}$ & $\begin{array}{c}26 . \\
4\end{array}$ \\
\hline $\begin{array}{c}\text { Mei } \\
201 \\
9\end{array}$ & $\begin{array}{l}2 \\
4\end{array}$ & $\begin{array}{l}25 . \\
46\end{array}$ & $\begin{array}{l}25 . \\
84\end{array}$ & $\begin{array}{c}26 . \\
14\end{array}$ & $\begin{array}{l}26 . \\
36\end{array}$ & $\begin{array}{c}26 . \\
5\end{array}$ & $\begin{array}{l}26 . \\
56\end{array}$ & $\begin{array}{c}26 . \\
54\end{array}$ & $\begin{array}{l}26 . \\
44\end{array}$ & $\begin{array}{l}26 . \\
26\end{array}$ \\
\hline $\begin{array}{c}\text { Jun } \\
201 \\
9\end{array}$ & $\begin{array}{l}2 \\
4\end{array}$ & $\begin{array}{c}24 . \\
14\end{array}$ & $\begin{array}{l}24 . \\
37\end{array}$ & $\begin{array}{c}24 . \\
64\end{array}$ & $\begin{array}{c}24 . \\
94\end{array}$ & $\begin{array}{l}25 . \\
25\end{array}$ & $\begin{array}{l}25 . \\
53\end{array}$ & $\begin{array}{l}25 . \\
78\end{array}$ & $\begin{array}{l}25 . \\
952\end{array}$ & $\begin{array}{c}26 . \\
034\end{array}$ \\
\hline $\begin{array}{c}\text { Jul } \\
201 \\
9\end{array}$ & 8 & $\begin{array}{c}24 . \\
01\end{array}$ & $\begin{array}{c}24 . \\
07\end{array}$ & $\begin{array}{c}24 . \\
19\end{array}$ & $\begin{array}{l}24 . \\
37\end{array}$ & $\begin{array}{c}24 . \\
62\end{array}$ & $\begin{array}{l}24 . \\
92\end{array}$ & $\begin{array}{l}25 . \\
24\end{array}$ & $\begin{array}{l}25 . \\
56\end{array}$ & $\begin{array}{r}25 . \\
83\end{array}$ \\
\hline $\begin{array}{c}\text { Agt } \\
201 \\
9\end{array}$ & $\begin{array}{l}1 \\
6\end{array}$ & $\begin{array}{c}9.6 \\
01\end{array}$ & $\begin{array}{l}11 . \\
22\end{array}$ & $\begin{array}{l}12 . \\
86\end{array}$ & $\begin{array}{l}14 . \\
55\end{array}$ & $\begin{array}{l}16 . \\
31\end{array}$ & $\begin{array}{l}18 . \\
15\end{array}$ & $\begin{array}{l}20 . \\
07\end{array}$ & $\begin{array}{l}22 . \\
05\end{array}$ & $\begin{array}{r}24 . \\
04\end{array}$ \\
\hline $\begin{array}{c}\text { Sep } \\
201 \\
9\end{array}$ & $\begin{array}{l}1 \\
1\end{array}$ & $\begin{array}{l}15 . \\
36\end{array}$ & $\begin{array}{l}15 . \\
04\end{array}$ & $\begin{array}{l}15 . \\
05\end{array}$ & $\begin{array}{l}15 . \\
42\end{array}$ & $\begin{array}{l}16 . \\
15\end{array}$ & $\begin{array}{l}17 . \\
29\end{array}$ & $\begin{array}{l}18 . \\
85\end{array}$ & $\begin{array}{c}20 . \\
84\end{array}$ & $\begin{array}{l}23 . \\
24\end{array}$ \\
\hline $\begin{array}{c}\text { Okt } \\
201 \\
9 \\
\end{array}$ & $\begin{array}{l}1 \\
0\end{array}$ & $\begin{array}{l}11 . \\
44\end{array}$ & $\begin{array}{l}11 . \\
81\end{array}$ & $\begin{array}{l}12 . \\
22\end{array}$ & $\begin{array}{l}12 . \\
77\end{array}$ & $\begin{array}{l}13 . \\
58\end{array}$ & $\begin{array}{l}14 . \\
78\end{array}$ & $\begin{array}{c}16 . \\
5\end{array}$ & $\begin{array}{l}18 . \\
87\end{array}$ & $\begin{array}{r}22 . \\
02\end{array}$ \\
\hline $\begin{array}{c}\text { No } \\
\text { V } \\
201 \\
9 \\
\end{array}$ & $\begin{array}{l}1 \\
7\end{array}$ & $\begin{array}{l}10 . \\
14\end{array}$ & $\begin{array}{l}10 . \\
36\end{array}$ & $\begin{array}{l}10 . \\
67\end{array}$ & $\begin{array}{l}11 . \\
11\end{array}$ & $\begin{array}{l}11 . \\
79\end{array}$ & $\begin{array}{l}12 . \\
87\end{array}$ & $\begin{array}{l}14 . \\
55\end{array}$ & $\begin{array}{l}17 . \\
09\end{array}$ & $\begin{array}{r}20 . \\
81\end{array}$ \\
\hline $\begin{array}{c}\text { Des } \\
201 \\
9\end{array}$ & $\begin{array}{l}2 \\
0\end{array}$ & $\begin{array}{l}16 . \\
32\end{array}$ & $\begin{array}{l}15 . \\
67\end{array}$ & $\begin{array}{c}15 . \\
1\end{array}$ & $\begin{array}{l}14 . \\
64\end{array}$ & $\begin{array}{l}14 . \\
39\end{array}$ & $\begin{array}{l}14 . \\
52\end{array}$ & $\begin{array}{l}15 . \\
28\end{array}$ & $\begin{array}{l}17 . \\
07\end{array}$ & $\begin{array}{r}20 . \\
43\end{array}$ \\
\hline
\end{tabular}

Kemudian dilakukan perhitungan akurasi peramalan pada hasil peramalan Tabel XIII. Hasil perhitungan akurasi peramalan permintaan Eyelash Single dengan Single Exponential Smoothing dapat dilihat pada tabel berikut

TABEL XIV

Hasil Perhitungan AKurasi Peramalan PermintaAn Eyelash SINGLE DENGAN SINGLE EXPONENTIAL SMOOTHING

\begin{tabular}{|l|c|c|c|c|c|c|c|c|c|}
\hline $\begin{array}{l}\text { Al } \\
\text { ph } \\
\text { a }\end{array}$ & $\mathbf{0 . 1}$ & $\mathbf{0 . 2}$ & $\begin{array}{c}\mathbf{0 .} \\
\mathbf{3}\end{array}$ & $\mathbf{0 . 4}$ & $\mathbf{0 . 5}$ & $\mathbf{0 . 6}$ & $\mathbf{0 .}$ & $\mathbf{0 . 8}$ & $\mathbf{0 . 9}$ \\
\hline RM & 6.4 & 6.3 & 20. & 20. & 21. & 21. & 22. & 22. & 24. \\
SE & 682 & 311 & 65 & 842 & 127 & 539 & 13 & 979 & 211 \\
\hline
\end{tabular}

Pada hasil perhitungan akurasi peramalan Tabel XIV, didapati bahwa peramalan Single Exponential Smoothing dengan nilai alpha $=0.2$ dapat menghasilkan nilai akurasi yang paling baik yaitu, 6.3311 .

\section{F. Peramalan Permintaan Facial Acne}

Permintaan treatment Facial Acne berdasarkan data historik ada pada Tabel I, data tersebut dilakukan perhitungan peramalan Simple Moving Average secara berturut-turut dengan nilai interval bervarian, mulai dari dua sampai delapan. Hasil perhitungan peramalan permintaan Facial Acne dengan Simple Moving Average dapat dilihat pada tabel berikut.

TABEL XV

Hasil Perhitungan Peramalan Permintaan FaCial ACNE DENGan SIMPLE MOVING AVERAGE

\begin{tabular}{|c|c|c|c|c|c|c|c|c|}
\hline $\begin{array}{c}\text { Interva } \\
1 \\
\end{array}$ & $\#$ & 2 & 3 & 4 & 5 & 6 & 7 & 8 \\
\hline Jan 2019 & $\begin{array}{l}1 \\
0 \\
\end{array}$ & & & & & & & \\
\hline $\begin{array}{c}\text { Feb } \\
2019\end{array}$ & 6 & & & & & & & \\
\hline $\begin{array}{c}\text { Mar } \\
2019 \\
\end{array}$ & $\begin{array}{l}1 \\
0 \\
\end{array}$ & 8 & & & & & & \\
\hline $\begin{array}{c}\text { Apr } \\
2019 \\
\end{array}$ & 8 & 8 & $\begin{array}{c}8.66 \\
7 \\
\end{array}$ & & & & & \\
\hline $\begin{array}{c}\text { Mei } \\
2019 \\
\end{array}$ & 2 & 9 & 8 & 8.5 & & & & \\
\hline Jun 2019 & 5 & 5 & $\begin{array}{c}6.66 \\
7\end{array}$ & 6.5 & $\begin{array}{l}7 . \\
2\end{array}$ & & & \\
\hline Jul 2019 & 3 & $\begin{array}{r}3 . \\
5 \\
\end{array}$ & 5 & $\begin{array}{c}6.2 \\
5 \\
\end{array}$ & $\begin{array}{l}6 . \\
2 \\
\end{array}$ & $\begin{array}{c}6.83 \\
3 \\
\end{array}$ & & \\
\hline $\begin{array}{c}\text { Agt } \\
2019\end{array}$ & 7 & 4 & 3.33 & 4.5 & $\begin{array}{l}5 . \\
6\end{array}$ & $\begin{array}{c}5.66 \\
7\end{array}$ & $\begin{array}{c}6.28 \\
5\end{array}$ & \\
\hline $\begin{array}{c}\text { Sep } \\
2019\end{array}$ & 4 & 5 & 5 & $\begin{array}{c}4.2 \\
5\end{array}$ & 5 & $\begin{array}{c}5.83 \\
3\end{array}$ & $\begin{array}{c}5.85 \\
7\end{array}$ & $\begin{array}{c}6.37 \\
5\end{array}$ \\
\hline $\begin{array}{c}\text { Okt } \\
2019\end{array}$ & $\begin{array}{l}1 \\
0\end{array}$ & $\begin{array}{l}5 . \\
5\end{array}$ & $\begin{array}{c}4.66 \\
7\end{array}$ & $\begin{array}{c}4.7 \\
5\end{array}$ & $\begin{array}{l}4 . \\
2\end{array}$ & $\begin{array}{c}4.83 \\
3\end{array}$ & $\begin{array}{c}5.57 \\
1\end{array}$ & $\begin{array}{c}5.62 \\
5\end{array}$ \\
\hline $\begin{array}{l}\text { Nov } \\
2019 \\
\end{array}$ & 6 & 7 & 7 & 6 & $\begin{array}{l}5 . \\
8\end{array}$ & $\begin{array}{c}5.16 \\
7 \\
\end{array}$ & $\begin{array}{c}5.57 \\
1 \\
\end{array}$ & $\begin{array}{c}6.12 \\
5\end{array}$ \\
\hline $\begin{array}{c}\text { Des } \\
2019\end{array}$ & 4 & 8 & $\begin{array}{c}6.66 \\
7\end{array}$ & $\begin{array}{c}6.7 \\
5\end{array}$ & 6 & $\begin{array}{c}5.83 \\
3\end{array}$ & $\begin{array}{c}5.28 \\
5\end{array}$ & $\begin{array}{c}5.62 \\
5\end{array}$ \\
\hline
\end{tabular}

Kemudian dilakukan perhitungan akurasi peramalan pada hasil peramalan Tabel XV. Hasil perhitungan akurasi peramalan permintaan Facial Acne dengan Simple Moving Average dapat dilihat pada tabel berikut.

\section{TABEL XVI}

Hasil Perhitungan AKurasi Peramalan PermintaAn FaCIAL ACNE DENGAN SIMPLE MOVING AVERAGE

\begin{tabular}{|l|c|c|c|c|c|c|c|}
\hline $\begin{array}{l}\text { Inter } \\
\text { val }\end{array}$ & $\mathbf{2}$ & $\mathbf{3}$ & $\mathbf{4}$ & $\mathbf{5}$ & $\mathbf{6}$ & $\mathbf{7}$ & $\mathbf{8}$ \\
\hline RMSE & $\begin{array}{c}3.170 \\
17\end{array}$ & $\begin{array}{c}10.46 \\
91\end{array}$ & $\begin{array}{l}3 \\
7\end{array}$ & $\begin{array}{c}33.41 \\
714\end{array}$ & $\begin{array}{c}32.81 \\
944\end{array}$ & $\begin{array}{c}32.76 \\
734\end{array}$ & $\begin{array}{c}35.35 \\
937\end{array}$ \\
\hline
\end{tabular}

Pada hasil perhitungan akurasi peramalan Tabel XVI, didapati bahwa peramalan Simple Moving Average pada treatment Facial Acne dengan nilai interval=2 merupakan nilai interval yang paling baik yaitu, 3.17017.

Selanjutnya dilakukan perhitungan peramalan metode Single Exponential Smoothing dengan nilai alpha mulai dari 0.1 sampai 0.9. Hasil peramalan permintaan Facial Acne dengan Single Exponential Smoothing dapat dilihat pada tabel berikut. 
TABEL XVII

Hasil Perhitungan Peramalan Permintaan Facial ACNe Dengan SINGLE EXPONENTIAL SMOOTHING

\begin{tabular}{|c|c|c|c|c|c|c|c|c|c|c|}
\hline $\begin{array}{c}\text { Alp } \\
\text { ha }\end{array}$ & $\#$ & $\begin{array}{l}0 . \\
1\end{array}$ & $\begin{array}{l}0 . \\
2\end{array}$ & $\begin{array}{l}0 . \\
3 \\
\end{array}$ & $\begin{array}{l}0 \\
4 \\
\end{array}$ & $\begin{array}{l}0 . \\
5\end{array}$ & $\begin{array}{l}0 . \\
6 \\
\end{array}$ & $\begin{array}{l}0 . \\
7 \\
\end{array}$ & $\begin{array}{l}0 . \\
8\end{array}$ & $\begin{array}{l}0 . \\
9 \\
\end{array}$ \\
\hline $\begin{array}{c}\text { Jan } \\
201 \\
9\end{array}$ & $\begin{array}{l}1 \\
0\end{array}$ & & & & & & & & & \\
\hline $\begin{array}{c}\text { Feb } \\
201 \\
9\end{array}$ & 6 & & & & & & & & & \\
\hline $\begin{array}{c}\text { Mar } \\
201 \\
9\end{array}$ & $\begin{array}{l}1 \\
0\end{array}$ & 6 & 6 & 6 & 6 & 6 & 6 & 6 & 6 & 6 \\
\hline $\begin{array}{c}\text { Apr } \\
201 \\
9\end{array}$ & 8 & 9.6 & 9.2 & 8.8 & 8.4 & 8 & 7.6 & 7.2 & 6.8 & 6.4 \\
\hline $\begin{array}{c}\text { Mei } \\
201 \\
9\end{array}$ & 2 & $\begin{array}{c}8.1 \\
6\end{array}$ & $\begin{array}{c}8.2 \\
4\end{array}$ & $\begin{array}{c}8.2 \\
4\end{array}$ & $\begin{array}{c}8.1 \\
6\end{array}$ & 8 & $\begin{array}{c}7.7 \\
6\end{array}$ & $\begin{array}{c}7.4 \\
4\end{array}$ & $\begin{array}{c}7.0 \\
4\end{array}$ & $\begin{array}{c}6.5 \\
6\end{array}$ \\
\hline $\begin{array}{c}\text { Jun } \\
201 \\
9\end{array}$ & 5 & $\begin{array}{l}2.6 \\
16\end{array}$ & $\begin{array}{l}3.2 \\
48\end{array}$ & $\begin{array}{l}3.8 \\
72\end{array}$ & $\begin{array}{l}4.4 \\
64\end{array}$ & 5 & $\begin{array}{l}5.4 \\
56\end{array}$ & $\begin{array}{l}5.8 \\
08\end{array}$ & $\begin{array}{l}6.0 \\
32\end{array}$ & $\begin{array}{l}6.1 \\
04\end{array}$ \\
\hline $\begin{array}{c}\text { Jul } \\
201 \\
9 \\
\end{array}$ & 3 & $\begin{array}{c}4.7 \\
6\end{array}$ & $\begin{array}{c}4.6 \\
5\end{array}$ & $\begin{array}{c}4.6 \\
6\end{array}$ & $\begin{array}{c}4.7 \\
8\end{array}$ & 5 & $\begin{array}{c}5.2 \\
7\end{array}$ & $\begin{array}{c}5.5 \\
6\end{array}$ & $\begin{array}{c}5.8 \\
2\end{array}$ & $\begin{array}{c}5.9 \\
9\end{array}$ \\
\hline $\begin{array}{c}\text { Agt } \\
201 \\
9\end{array}$ & 7 & $\begin{array}{l}3.1 \\
76\end{array}$ & $\begin{array}{l}3.3 \\
29\end{array}$ & $\begin{array}{l}3.4 \\
98\end{array}$ & $\begin{array}{l}3.7 \\
14\end{array}$ & 4 & $\begin{array}{c}4.3 \\
6\end{array}$ & $\begin{array}{c}4.7 \\
9\end{array}$ & $\begin{array}{c}5.2 \\
6\end{array}$ & $\begin{array}{c}5.6 \\
9\end{array}$ \\
\hline $\begin{array}{c}\text { Sep } \\
201 \\
9\end{array}$ & 4 & $\begin{array}{l}6.6 \\
17\end{array}$ & $\begin{array}{l}6.2 \\
66\end{array}$ & $\begin{array}{l}5.9 \\
49\end{array}$ & $\begin{array}{l}5.6 \\
85\end{array}$ & 5.5 & $\begin{array}{l}5.4 \\
18\end{array}$ & $\begin{array}{l}5.4 \\
57\end{array}$ & $\begin{array}{l}5.6 \\
08\end{array}$ & $\begin{array}{l}5.8 \\
25\end{array}$ \\
\hline $\begin{array}{c}\text { Okt } \\
201 \\
9\end{array}$ & $\begin{array}{l}1 \\
0\end{array}$ & $\begin{array}{c}4.2 \\
61\end{array}$ & $\begin{array}{l}4.4 \\
53\end{array}$ & $\begin{array}{l}4.5 \\
85\end{array}$ & $\begin{array}{l}4.6 \\
74\end{array}$ & $\begin{array}{c}4.7 \\
5\end{array}$ & $\begin{array}{c}4.8 \\
51\end{array}$ & $\begin{array}{c}5.0 \\
2\end{array}$ & $\begin{array}{l}5.2 \\
86\end{array}$ & $\begin{array}{l}5.6 \\
42\end{array}$ \\
\hline $\begin{array}{c}\text { Nov } \\
201 \\
9 \\
\end{array}$ & 6 & $\begin{array}{l}9.4 \\
26\end{array}$ & $\begin{array}{c}8.8 \\
9\end{array}$ & $\begin{array}{l}8.3 \\
75\end{array}$ & $\begin{array}{l}7.8 \\
69\end{array}$ & $\begin{array}{l}7.3 \\
75\end{array}$ & $\begin{array}{c}6.9 \\
1\end{array}$ & $\begin{array}{l}6.5 \\
14\end{array}$ & $\begin{array}{l}6.2 \\
29\end{array}$ & $\begin{array}{l}6.0 \\
78\end{array}$ \\
\hline $\begin{array}{c}\text { Des } \\
201 \\
9\end{array}$ & 4 & $\begin{array}{l}6.3 \\
42\end{array}$ & $\begin{array}{l}6.5 \\
78\end{array}$ & $\begin{array}{l}6.7 \\
12\end{array}$ & $\begin{array}{l}6.7 \\
48\end{array}$ & $\begin{array}{l}6.6 \\
87\end{array}$ & $\begin{array}{l}6.5 \\
46\end{array}$ & $\begin{array}{c}6.3 \\
59\end{array}$ & $\begin{array}{l}6.1 \\
83\end{array}$ & $\begin{array}{c}6.0 \\
7\end{array}$ \\
\hline
\end{tabular}

Kemudian dilakukan perhitungan akurasi peramalan pada hasil peramalan Tabel XVII. Hasil perhitungan akurasi peramalan permintaan Facial Acne dengan Single Exponential Smoothing dapat dilihat pada tabel berikut

$$
\text { TABEL XVIII }
$$

Hasil Perhitungan Akurasi Peramalan PermintaAn FaCial ACNE DENGAN SINGLE EXPONENTIAL SMOOTHING

\begin{tabular}{|l|c|c|c|c|c|c|c|c|c|}
\hline $\begin{array}{l}\text { Al } \\
\text { ph } \\
\text { a }\end{array}$ & 0.1 & $\mathbf{0 . 2}$ & $\mathbf{0 . 3}$ & $\mathbf{0 . 4}$ & $\mathbf{0 . 5}$ & $\mathbf{0 . 6}$ & $\mathbf{0 . 7}$ & $\mathbf{0 . 8}$ & $\mathbf{0 . 9}$ \\
\hline RM & 3.7 & 3.5 & 6.3 & 6.2 & 6.18 & 6.1 & 6.0 & 6.0 & 6.0 \\
SE & 002 & 572 & 397 & 562 & 001 & 164 & 725 & 517 & 428 \\
\hline
\end{tabular}

Pada hasil perhitungan akurasi peramalan Tabel XVIII, didapati bahwa peramalan Single Exponential Smoothing dengan nilai alpha $=0.2$ dapat menghasilkan nilai akurasi yang paling baik yaitu, 3.5572 .

\section{KESIMPULAN}

Dari hasil pengembangan aplikasi pendukung keputusan peramalan permintaan treatment kecantikan dengan metode Simple Moving Average dan Single Exponential Smoothing didapat nilai interval $=2$ dan nilai alpha $=0.2$ merupakan nilai konstanta yang paling optimal karena dapat menghasilkan akurasi paling baik. Simple Moving Average juga lebih unggul pada peramalan permintaan BB Glow Platinum, Eyelash Single, dan Facial Acne. Pengembangan aplikasi pendukung keputusan dapat melakukan manajemen pengguna dan perhitungan peramalan permintaan yang mengikuti database. Dengan demikian decision maker dapat terbantu dalam menentukan prioritas persediaan dan langkah strategi penjualan.

\section{UCAPAN TERIMA KASIH}

Penulis ingin mengucapkan terima kasih khusus kepada pemilik DS Beauty and Skincare, Sasi Fatmawati yang telah memberikan izin dan data guna penelitian peramalan permintaan layanan kecantikan dengan Simple Moving Average dan Single Exponential Smoothing.

\section{DAFTAR PUSTAKA}

[1] S. Mauliyana and D. Lutfiati, "PENGARUH MINAT DAN MOTIVASI KONSUMEN REMAJA DALAM PEMILIHAN JENIS PERAWATAN WAJAH DI NANISA BEAUTY \& DENTAL CLINIC SIDOARJO Shofiana Mauliya," J. Tata Rias, vol. 5 , no. 3, p. 60, 2016.

[2] E. Dewi Setia Tarigan, "PENGARUH GAYA HIDUP, LABEL HALAL DAN HARGA TERHADAP KEPUTUSAN PEMBELIAN KOSMETIK WARDAH PADA MAHASISWA PROGRAM STUDI MANAJEMEN FAKULTAS EKONOMI UNIVERSITAS MEDAN AREA MEDAN," J. Konsep Bisnis dan Manaj., vol. 3, p. 1, 2016.

[3] E. P H Li, H. Jeong Min, R. W Belk, J. Kimura, and S. Bahl, "Skin Lightening and Beauty in Four Asian Cultures," Adv. Consum. Res. vol. 35, pp. 444-449, 2008.

[4] N. Marlianti and A. Suryani, "REPRESENTASI TUBUH PEREMPUAN DALAM RUBRIK KECANTIKAN DI MAJALAH FEMINA EDISI MEI 2011," J. Komunikologi, vol. 9, p. 2, 2012.

[5] A. Raharja, W. Angraeni, and R. Aulia Vinarti, "PENERAPAN METODE EXPONENTIAL SMOOTHING UNTUK PERAMALAN PENGGUNAAN WAKTU TELEPON DI PT.TELKOMSEL DIVRE3 SURABAYA," J. Sist. Inf., vol. 59, p. 73, 2017.

[6] K. V. and H. Fuks, "Beauty Technology: Body Surface Computing," Computer (Long. Beach. Calif)., vol. 47, no. 4, pp. 71-75, Apr. 2014.

[7] D. A. Setiawan, S. Wahyuningsih, and R. Goejantoro, "Peramalan Produksi Kelapa Sawit Menggunakan Winter's dan Pegel's Exponential Smoothing dengan Pemantauan Tracking Signal," Jambura J. Math., vol. 2, no. 1, pp. 1-14, Dec. 2019.

[8] B. U. Putra Manurung, "IMPLEMENTASI LEAST SQUARE DALAM UNTUK PREDIKSI PENJUALAN SEPEDA MOTOR ( STUDI KASUS : PT . GRAHA AUTO PRATAMA )," J. Ris. Komput., vol. 2, pp. 21-24, 2015.

[9] W. Kurniadi, "Pendukung Keputusan Dalam Peramalan Penjualan Ayam Broiler Dengan Metode Trend Moment Dan Simple Moving Average," MEDIA Inform. BUDIDARMA, vol. 2, pp. 76-90, 2018.

[10] N. Hudaningsih et al., "PERBANDINGAN PERAMALAN PENJUALAN PRODUK AKNIL PT . SUNTHI SEPURI MENGGUANAKAN METODE SINGLE MOVING AVERAGE DAN SINGLE EXPONENTIAL SMOOTING," J. JINTEKS, vol. 2, pp. $15-22,2020$.

[11] R. Gustriansyah, "Analisis Metode Single Exponential Smoothing Dengan Brown Exponential Smoothing Pada Studi Kasus Memprediksi Kuantiti Penjualan Produk Farmasidi Apotek," in Seminar Nasional Teknologi Informasi dan Multimedia 2017, 2017, vol. 3, pp. 5-12.

[12] R. Safitri, "Penerapan Metode Single Exponential Untuk Peramalan Volume Penjualan Minuman Kemasan (Studi Kasus: PT Coca Cola Amatil Indonesia Medan), J. Ris. Komput., vol. 6, no. 1, pp. 100-105, 2019.

[13] M. A. Islam, H. S. Che, M. Hasanuzzaman, and N. A. Rahim, 
"Energy demand forecasting," in Energy for Sustainable Development, Elsevier, 2020, pp. 105-123.

[14] H. Utari and N. Silalahi, "Perancangan aplikasi peramalan permintaan kebutuhan tenaga kerja pada perusahaan outsourcing menggunakan algoritma simple moving average," J. TIMES, vol. 5, no. 2, pp. 1-5, 2016.

[15] H. H. Nguyen and Y. Zhaojun, "Profitability of Applying Simple Moving Average Trading Rules for the Vietnamese Stock Market," J. Bus. Manag., vol. 2, no. 3, pp. 22-31, Sep. 2013.

[16] S. R. SY, "ANALISIS PENYIMPANAN DAN PENGELUARAN BAHAN CURAH PT SEMEN PADANG," J. Optimasi Sist. Ind., vol. 10, pp. 105-112, 2011.

[17] R. Effendi, J. O. Ong, and A. S. Gunawan, "PENERAPAN SISTEM KLASIFIKASI ABC DAN KOMBINASI FORECASTING SEBAGAI PENDUKUNG KEPUTUSAN DI DALAM SISTEM INFORMASI PENGADAAN BARANG," $J$ Telemat., vol. 7, p. 1, 2011.

[18] B. Siregar, I. A. Butar-Butar, R. Rahmat, and U. A. and F. Fahmi, "International Conference on Recent Trends in Physics 2016 (ICRTP2016)," J. Phys. Conf. Ser., vol. 755, p. 011001, Oct. 2016.

[19] I. Falani, "Penentuan Nilai Parameter Metode Exponentia Smoothing Dengan Algoritma Genetik Dalam Meningkatkan Akurasi Forecasting," CESS (Journal Comput. Eng. Syst. Sci., vol. 3, no. 1, pp. 14-16, 2018.

[20] W. Wang and Y. Lu, "Analysis of the Mean Absolute Error (MAE) and the Root Mean Square Error (RMSE) in Assessing Rounding Model," IOP Conf. Ser. Mater. Sci. Eng., vol. 324, p. 012049, Mar. 2018.

[21] T. Chai and R. R. Draxler, "Root mean square error (RMSE) or mean absolute error (MAE)?," Geosci. Model Dev. Discuss., vol. 7, no. 1, pp. 1525-1534, Feb. 2014

[22] L. Mentaschi, G. Besio, F. Cassola, and A. Mazzino, "Problems in RMSE-based wave model validations," Ocean Model., vol. 72, pp. 53-58, Dec. 2013.

[23] S. W. Setyawan, W. Witanti, and A. I. Hadiana, "Sistem Informasi Penjadwalan Produksi Pada PT Nickel Chrome Indo Jaya," in Seminar Nasional Teknologi Komputer \& Sains (SAINTEKS), 2020, pp. $117-121$.

[24] A. Putra and A. Azhari, "SISTEM DATA TAMU DAN KONSULTASI TAMU KANTOR REGIONAL VII BKN PALEMBANG BERBASIS WEB MOBILE," Semin. Has. Penelit. Vokasi, vol. 1, p. 2, 2020.

[25] H. Kurniawan, W. Apriliah, I. Kurniawan, D. Firmansyah, S. Informasi, and S. Pinjam, "PENERAPAN METODE WATERFALL DALAM PERANCANGAN SISTEM INFORMASI PENGGAJIAN PADA SMK BINA KARYA KARAWANG," J. Interkom, vol. 14, pp. 13-23, 2020.

[26] H. Pangestu, H. Alianto, and S. F. Wijaya, "Hasil Rancang Bangun Sistem ERP dengan SDLC Model Waterfall: Studi Kasus Sistem Inventori PT Pan Brothers, Tbk.," ComTech Comput. Math. Eng. Appl., vol. 3, no. 2, p. 1036, Dec. 2012.

[27] K. Siau and Y. Tian, "The Complexity of Unified Modeling Language : A GOMS Analysis," in ICIS 2001, 2001, vol. 53.

[28] G. H. Travassos, F. Shull, and J. Carver, "Working with UML: A software design process based on inspections for the unified modeling language," in ADVANCES IN COMPUTERS, vol. 54, 2002, pp. 35-98

[29] K. Baclawski et al., "Extending the Unified Modeling Language for ontology development," Softw. Syst. Model., vol. 1, no. 2, pp. 142-156, Dec. 2002.

[30] J. Davies and C. Crichton, "Concurrency and Refinement in the Unified Modeling Language," Form. Asp. Comput., vol. 15, pp. $118-145,2003$.

[31] C. Supaartagorn, "PHP Framework for Database Management Based on MVC Pattern,” Int. J. Comput. Sci. Inf. Technol., vol. 3, no. 2, pp. 251-258, Apr. 2011.

[32] M. Jailia, A. Kumar, M. Agarwal, and I. Sinha, "Behavior of MVC (Model View Controller) based Web Application developed in PHP and .NET framework," in ICT in Business Industry \& Government (ICTBIG), 2016.

[33] E. Curry and P. Grace, "Flexible Self-Management Using the Model-View-Controller Pattern," IEEE Softw., vol. 25, no. 3, pp. 84-90, May 2008.

[34] A. Leff and J. T. Rayfield, "Web-application development using the Model/View/Controller design pattern," in Proceedings Fifth IEEE International Enterprise Distributed Object Computing
Conference, 2001, pp. 118-127.

[35] M. Ehmer Khan, "Different Approaches To Black box Testing Technique For Finding Errors," Int. J. Softw. Eng. Appl., vol. 2, no. 4, pp. 31-40, Oct. 2011. 